\title{
Differentiated Rewards as an Enticement to Display and Develop More Professionalism in Higher Professional Education
}

\section{-Perceptions of Justice among the Lecture Staff}

\author{
Jol Stoffers, Erik Canisius \\ Research Centre of Employability, Zuyd University of Applied Sciences, Heerlen-Maastricht-Sittard, \\ The Netherlands \\ Email: jol.stoffers@zuyd.nl
}

Received 12 March 2015; accepted 21 April 2015; published 22 April 2015

Copyright (C) 2015 by authors and Scientific Research Publishing Inc.

This work is licensed under the Creative Commons Attribution International License (CC BY).

http://creativecommons.org/licenses/by/4.0/

(c) (i) Open Access

\section{Abstract}

This research investigates to what extent lecturers at universities of applied sciences do regard differentiated rewards-intended to develop and/or display professionalism-to be fair, and to what extent, and in which form, do these stimulate their willingness to (further) professionalise and/or display professionalism. This was a case study research design, and a factorial survey measurement technique was used to collect data. We argue that lecturers believe it is fair that forms of differentiated rewards are used and applied in order to have them develop and/or display more professionalism. Especially the viewpoints/practices that relate to coordination, consultation, and consideration for personal circumstances have an influence on the justice perceived. This paper contributes to the HRM literature confirming that lecturers appreciate financial stimuli enhancing their professionalism; however, elements such as consultation, respect, coordination, and communication are appreciated even more. It appeals to HRM to design new practices which have more stimulating effect on personal and professional growth in subject-specific knowledge.

\section{Keywords}

HRM, Perceived Fairness, Differentiated Rewards, Willingness to Professionalise, Factorial Survey Technique

\section{Introduction}

Discussions about the quality of higher education providers have put higher education in the Netherlands under

How to cite this paper: Stoffers, J. and Canisius, E. (2015) Differentiated Rewards as an Enticement to Display and Develop More Professionalism in Higher Professional Education. Journal of Human Resource and Sustainability Studies, 3, 57-65. http://dx.doi.org/10.4236/jhrss.2015.32009 
quite some pressure [1]. On the one hand, the declining quality is caused by a changing student population, greater emphasis on expansion, and the efficiency measures that these entail. On the other hand, the lecture staff at universities of applied sciences are expected to put more effort in order to safeguard and upgrade higher professional education. If we are to meet all these developments and ambitions, lecturer professionalisation is essential. Van Veen, et al. [1] found that when it came to improving the quality as well as the image of education, the professional development of lecturers was regarded as an indispensable tool.

In actual practice, however, it turns out that there are ample facilities for lecturer professionalisation, but that the lecturers at universities of applied sciences rarely draw on them. Lecture staff are scarcely encouraged to engage in professionalisation, and there are no deterrents for not doing so either. In other words, lecturers are poorly motivated to invest in their own professional and personal development. Lecturers at universities of applied sciences do believe, however, that the deployment and application of differentiated rewards and specific arrangements, all focused on developing and/or displaying professionalism, are justified and-under certain conditions-encourage them to do so.

(Representative) consultation, coordination, communication, and consideration of personal circumstances are each aspects that are relevant within a process of lecturer professionalisation, and together they form a stimulus for further professionalisation and are all believed to be justified.

This paper will first explain why it is important and evident for lecturers at universities of applied sciences to continually and structurally develop their professional and personal skills and whether they believe that the use and application of differentiated rewards as tools to encourage professionalisation are justified. For the purpose of clarity, concepts such as differentiated rewards, lecturer professionalisation and organisational justice will be presented and defined. The selected and applied research methodology will also be clarified briefly. Finally, this paper will present the main research outcomes, enumerate the results, draw conclusions, and briefly discuss the limitations of, and suggestions for, further research.

\section{Literature Review}

\subsection{The Necessity of Lecturer Professionalisation}

The Ministry of Education, Culture and Science, the Netherlands Association of Universities of Applied Sciences, and other "authoritative" institutions are increasingly emphasising the importance of lecturer professionalisation, claiming that the changing demands on education automatically, but also evidently, have consequences for the lecturers who will have to fulfill these continually changing demands. After all, lecturers are the basis of educational quality: only high-quality lecturers with a proper expertise and the ability to grip and hold attention can provide the education that is needed. In the light of these developments, lecturers at universities of applied sciences clearly have to come better prepared when it comes to the contents of their subjects. It cannot be disputed that higher professional education must have a stronger bond with practice-focused research if students at universities of applied sciences are to graduate as innovative young professionals.

However, studies and research such as the Strategic Agenda for Higher Education, Research and Science [2] and the Education Council [3] revealed that the professionalisation of lecturers in the Netherlands needs serious improvement.

Diepstraten, et al. [4] found that the lack of professional behaviour among lecturers as a vocational group has two causes. Firstly, there is quite some dissatisfaction and demotivation among lecturers, whereas motivation is actually vital in a process of lecturer professionalisation. It also turns out that lecturers are generally not very open to change and fail to properly realise the need for lifelong learning. On the other hand, lecturers are often not explicitly obligated to take part in professionalisation programmes, do not receive a raise in salary or any other financial incentive if they do, and, moreover, participation hardly ever leads to promotion.

According to Martens [5], motivation plays a key role in behavioural changes in general, and so this must also apply in the case of lecturer professionalisation. Latham and Pinder [6] defined motivation as a psychological process that is the result of the interaction between the individual and their environment. Watt and Richardson [7] stated that, in the context of lecturer professionalisation, extrinsic motivation implies that lecturers deliver performance for some type of reward, such as obtaining a diploma.

\subsection{Lecturer Professionalisation and Differentiated Rewards}

According to Hildebrandt and Eom [8] and Hess Rice [9], financial gain is a powerful, appealing, and initial 
stimulus in the process of professionalisation. They added that if lecturers receive a financial reward for their participation in professionalisation activities, this has a positive effect on future lecturer professionalisation.

The reasons for lecturers to display little professional behaviour or any active form of professionalisation, are both internal (the lecturers themselves) and external (arising from their environment). Central to this paper is the external reason, especially the degree to which differentiated rewards entice the lecturers at universities of applied sciences to display and/or develop more professional behaviour and whether they consider them justified.

Although the literature, for example Clugston, Howell and Dorman [10], shows that differentiated rewards can encourage characteristics of professional behaviour, it is unknown as to whether lecturers at universities of applied sciences find them fair and are, therefore, prepared to display behaviour that result in professionalisation, or whether it is the deployment of differentiated rewards that encourages them to do so.

It is, after all, the lecturers' own intention that determines and decides whether they do, or do not, participate in professionalisation activities. HRM instruments, for instance, may influence lecturers' behaviour and thereby contribute to more competent lecturers who will be more motivated to develop more professionalism and professionalise further.

There are widely varying views and interpretations when it comes to the motivational effect of differentiated rewards in the context of lecturer professionalisation.

According to Ballou and Pogursky [11], Chamberlin, et al. [12] and Solmon and Pogursky [13], highly qualified staff, including lecturers, are drawn to organisations where their knowledge and skills (and their continual development) are rewarded.

Chamberlin, et al. [12] arrived at a more thoughtful judgement. They stated that by appreciating certain aspects of the work, rewards merely show which aspects are appreciated and which type of behaviour is desired.

\subsection{Differentiated Rewards}

In this paper, the definition of the concept of differentiated rewards by Hay Management Consultants [14] is used, as it is the most encompassing and often used in studies into issues of rewards in the public sector. For the sake of completeness, the definition is as follows: "every form of making a distinction in rewarding individuals or groups of staff and for which motivation is found in rewards other than the job scale rating, the level on the salary scale and periodic or annual pay raises” (p. 1). These are ultimately the points of departure for differentiated rewards, but they may have a counterproductive effect: employees will be encouraged to develop certain competences in such a way, that they will neglect others. Mulders [15] was even more outspoken and asserted that the prospect of the reward will make employees do everything they can to lay their hands on it. On the one hand, this may improve the performance of the lecturers, as they will fully focus on professionalisation. On the other hand, however, the performance of the organisation as a whole may suffer.

In accordance with the definition by Hay Management Consultants [14] that refers to distinctions in rewarding individuals or groups of staff, this paper will refer to individual rewards when it comes to "rewarding individuals". For "rewarding groups of staff", the term team rewards will be used.

According to Hildebrandt and Eom [8] and Hess Rice [9], financial gain is a powerful, appealing, and initial stimulus in the process of professionalisation. This stimulus should be used as a booster within the process of professionalisation, albeit that the appeal of the financial incentive will tone down once other motivational stimuli grow stronger. Van der Heijden [16] concluded, if lecturers receive a financial reward for their participation in professionalisation activities, this has a positive effect on future lecturer professionalisation activities.

\subsection{Organisational Justice}

When people in organisations feel they are justly treated, this often increases their motivation and involvement and their feeling of appreciation. Therefore, this paper is written on the basis of the gap found in the literature between the impact of differentiated rewards on the willingness of lecturers at universities of applied sciences to further professionalise, and to what extent these lecturers believe the deployment of different types of differentiated rewards in order for them to develop and display their professionalism to be fair.

How fair, or just, do lecturers at universities of applied sciences regard the deployment and application of differentiated rewards as a means to encourage them to develop and display their professionalism? 
Consideration of justice within organisations is closely linked to the concept of "employees trust" and has a long tradition within the domain of Organisational Behaviour [17].

How just do lecturers at universities of applied sciences believe it to be that different types of reward differentiation are applied to increase professionalism? To what degree do these stimulate their willingness to further professionalise or display more professionalism?

These are the main questions:

To what extent do lecturers at universities of applied sciences regard differentiated rewards-intended to develop and/or display professionalism — to be fair, and to what extent, and in which form, do these stimulate their willingness to (further) professionalise and/or display professionalism? (See also Figure 1.)

The partial questions derived from these main questions are as follows:

- To what extent do lecturers at universities of applied sciences regard differentiated rewards—intended to develop and/or display professionalism — to be fair?

- To what extent are lecturers at universities of applied sciences willing to (further) professionalise and/or display their professionalism when (forms of) differentiated rewards are used?

- Is there a relationship between the fairness perceived and the willingness of lecturers at universities of applied sciences to (further) professionalise and/or display their professionalism when (forms of) differentiated rewards are used?

\section{Research Methodology}

The research strategy employed was an embedded case study according to Saunders, Lewis and Thornhill [18]. The case study strategy was chosen because a university of Applied Sciences is a typical case of higher education in the Netherlands. Case studies can be used for different types of research purposes, including theory building, which identify and describe key variables and their linkages, and theory testing.

This research is based on a number of factorial surveys that were administered to all the lecturers at a medium-sized faculty of a University of Applied Sciences. This measurement technique was developed by Rossi [19] for the purpose of observing how individuals and segments of populations integrate various dimensions of information when forming judgments about complex social phenomema. The factorial survey technique (or vignette study) combines the benefits of traditional survey research with those associated with the experimental design. In essence, a factorial survey comprises short descriptions and questions about fictional or hypothetical aspects that are put before the respondents. These fictional cases are translated into scenarios, also referred to as vignettes, which are manipulated by the researcher [20]. This type of research design, referred to as a factorial survey, is often used to study judgements about justice and is very useful in collecting data that cannot be easily obtained through traditional research methods. The use of vignettes allows the researcher to examine the respondents' preferences.

In this study, the respondents were questioned through various vignettes-with different contexts. Each respondent received a unique set of vignettes. Each vignette comprised a systematically prepared description of a concrete, but hypothetical situation. The questions per vignette (on individual or team rewards) investigated, on the one hand, to which extent the respondents believed the described vignette situation, which each pertained to a specific reward as a stimulus for further professionalisation, to be justified. These closed questions had to be scored on a 5-point Likert scale, ranging from "very fair" to "very unfair".
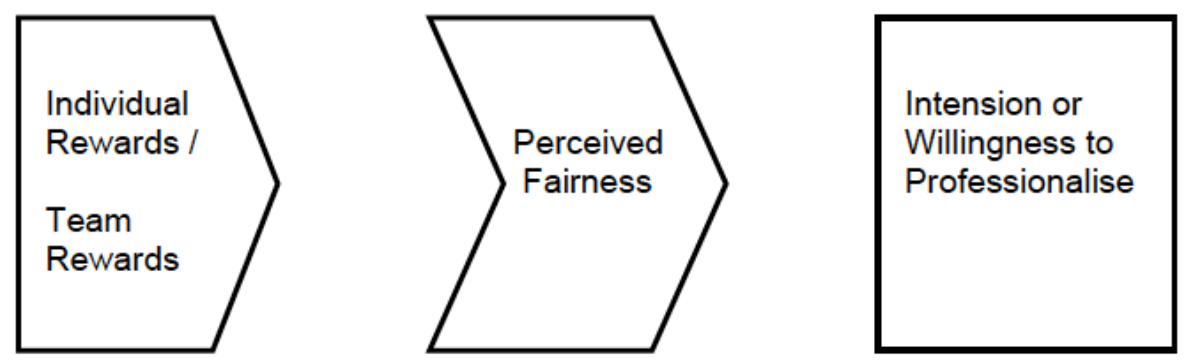

Figure 1. The emergence of more intension or willingness to professionalise through differentiated rewards. 
In both vignettes (individual and team rewards), the questions were characterised by an alternating inclusion of the variables of form, amount, (representative) consultation, and respect. Based on these different variables, which (may) play a role in the emergence, or not, of a feeling of justice with respect to the application of various forms of differentiated rewards as stimuli for professionalisation, and given our own ambition to include each of these variables explicitly and distinctively, two separate vignettes were designed. Each unique vignette generically represented one of the two types of differentiated rewards: individual and team rewards. The vignettes helped to put the respondents' focus on specific, independent variables. The variables in the vignettes were the conditions that formed the context.

In the construction of the vignettes the focus was on four variables:

- The form of reward.

- The amount of the reward.

- Any (representative) involvement in the decision-making (consultation).

- The respect that the reward showed.

In both vignettes (on individual and team rewards), the questions were characterised by an alternating application of the variables of form, amount, consultation, and respect. These will be clustered in the analysis of the results in this paper, for the purpose of readability. The general questions also included a set of classifiable variables, such as gender, discipline, working hours, and education. The point of departure for the questions per vignette was to measure the perceived fairness of the four reward variables of amount, form, consultation, and the respect it showed.

Although the two vignettes differed in terms of content, and the statements per vignette were specifically geared to this content, we strove towards uniformity in the statements per vignette. This uniformity was based on the aspects of feelings of justice that were tackled in the statements in all the vignettes, for those were the same for each type of differentiated reward. This means that the research results:

- could be analysed vertically; an inventory could be made per vignette, and so per type of differentiated reward, of the feelings of justice (in its various aspects) that went together with the application of the differentiated rewards, so that the feelings of justice within a specific type could be explicated;

- could be analysed horizontally; due to the aforementioned uniformity in the statements of each set of vignettes, it was possible to assess whether there were any significant differences in (aspects of) the feelings of justice about the two types of differentiated rewards, so that any differences in the feelings of justice between the specific types of differentiated rewards could be explicated.

There were 56 respondents (63\%) on the individual rewards vignette and 42 respondents (47\%) on the team rewards vignette. From the respondents on the individual reward vignette, 31 were men (55\%) and 25 were women (45\%). In addition, 10 of the respondents were $<40$ years old (18\%) and 46 were $\geq 40$ years old (82\%). Their mean age was 45 years old, and their average length of service for the organization was 10.8 years. From the respondents on the team reward vignette, 25 were men (57\%) and 17 were women (43\%). In addition, 17 of the respondents were $<40$ years old (17\%) and 35 were $\geq 40$ years old ( $83 \%$ ). Their mean age was 46 years old, and their average length of service for the organization was 11.1 years. Most of the respondents had a master's degree.

\section{Results}

The main question of this paper is: To what extent do lecturers at universities of applied sciences regard differentiated rewards - intended to develop and/or display professionalism — to be fair, and to what extent, and in which form, do these encourage their willingness to (further) professionalise and/or display professionalism?

The percentage of the response to the vignettes provided a representative population sample.

Lecturers at universities of applied sciences believe it is fair, forms of differentiated rewards are used and applied in order to have them develop and/or display more professionalism. Especially the viewpoints/practices that relate to coordination, consultation, and consideration for personal circumstances have an influence on the justice perceived. An additional reward in the form of time compensation is also perceived as fair.

The application and deployment of forms of differentiated rewards have a positive influence on these lecturers' willingness to (further) develop and/or display their professionalism. A financial incentive is a stimulus for these lecturers to display more professionalism. Another powerful stimulus is the management's communication with the lecturer about the prerequisites and the amount of the reward. 
There is a relationship between the fairness perceived and the willingness of lecturers at universities of applied sciences to (further) professionalise and/or display their professionalism if certain viewpoints and practices are adhered to. The viewpoints/practices that have to do with consultation, discussion, coordination, and consideration for personal circumstances have great value within a process of lecturer professionalisation. Where these viewpoints and practices are concerned, we found a relationship between the lecturers' willingness to (further) professionalise and the perceived fairness of a practice or viewpoint.

\section{Discussion and Conclusions}

On the basis of the results, we may conclude that lecturers at universities of applied sciences experience specific practices/viewpoints adopted by the management in a process of lecturer professionalisation to be fair, that a financial incentive may be a powerful stimulus, and that, emphatically, viewpoints/practices that relate to consultation, discussion, and coordination have major relevance within the process. For both individual and team rewards, it applies that the practices/viewpoints which relate to discussion, consultation, coordination, and consideration for personal circumstances are by far the most attributive towards their believing that the deployment and application of these types of rewards in order to entice them to develop and/or display their professionalism is fair and also encourage them to show more willingness to further professionalise (see also Table 1 and Table 2 for further details).

Obviously, the vignette method also has its limitations. It enables the researcher to examine preferences. Vignettes are systematically prepared descriptions of concrete situations and are assembled from characteristics that are expected to be important in the decision-making that is being researched.

In this study, the respondents received a questionnaire which presented, in brief, different viewpoints or practices of the management as coherent alternatives. It was then up to the respondents to pass judgement. The respondents were thus expected to make a comparative assessment. The limitation of this method was that it merely asked for the respondent's perception, as the respondents had to imagine themselves in the situation described and consider what they would do in this situation. Therefore, it was not actual behaviour that was measured, but their intentions! Fishbein and Ajzen [21] assumed that intentions were indications of how hard people were prepared to try to put the relevant behaviour into practice.

\begin{tabular}{|c|c|c|c|}
\hline Views/practices & Relevance & (Un)fairness & Level of stimulant \\
\hline 1. Lecturer receives in their tasks plate 25 extra hours as reward. & Neutral & Fair & Neutral to substantially \\
\hline $\begin{array}{l}\text { 2. About the amount of the reward and the conditions of } \\
\text { professionalizing is no discussion possible with the management. }\end{array}$ & Great & Unfair & Scarce \\
\hline 3. Lecturer receives a periodic as reward. & Neutral & Neutral & Substantially \\
\hline $\begin{array}{l}\text { 4. No voice is heard concerning the conditions and the specific } \\
\text { professionalization. }\end{array}$ & Great & Unfair & Scarce \\
\hline $\begin{array}{l}\text { 5. Lecturer receives a total payback of expenses and a reward of } \\
€ 100 \text {. }\end{array}$ & Neutral to great & Reasonable & Neutral \\
\hline $\begin{array}{l}\text { 6. Personal conditions of the professionalizing lecturer will not be } \\
\text { taken into account. }\end{array}$ & Great & Unfair & Scarce \\
\hline 7. Lecturer receives $€ 100$ as a reward. & Neutral & Neutral & Scarce to neutral \\
\hline 8. Lecturer receives a total expense payback. & Neutral to great & Reasonable & Neutral to substantially \\
\hline $\begin{array}{l}\text { 9. Management communicates with lecturer about the } \\
\text { preconditions and the amount of the reward. }\end{array}$ & Great & Reasonable & Substantially \\
\hline 10. Lecturer receives a coupon of $€ 75$ as reward. & Neutral & Neutral & Scarce to neutral \\
\hline
\end{tabular}


Table 2. Summary and results team reward.

\begin{tabular}{|c|c|c|c|}
\hline Views/practices & Relevance & (Un)fairness & Level of stimulant \\
\hline 1. Lecturer receives in their tasks plate 25 extra hours as reward. & Neutral to great & Reasonable & Neutral \\
\hline $\begin{array}{l}\text { 2. About the amount of the reward and the conditions of } \\
\text { professionalizing is no discussion possible with the management. }\end{array}$ & Great & Unfair & Scarce \\
\hline 3. Lecturer receives a periodic as reward. & Neutral to great & Neutral & Neutral to substantially \\
\hline $\begin{array}{l}\text { 4. No voice is heard concerning the conditions and the specific } \\
\text { professionalization. }\end{array}$ & Great & Unfair & Scarce \\
\hline $\begin{array}{l}\text { 5. Lecturer receives a total payback of expenses and a reward of } \\
€ 100 .\end{array}$ & Neutral to great & $\begin{array}{l}\text { Neutral to } \\
\text { reasonable }\end{array}$ & Neutral \\
\hline $\begin{array}{l}\text { 6. Personal conditions of the professionalizing lecturer will not be } \\
\text { taken into account. }\end{array}$ & Great & $\begin{array}{l}\text { Unreasonable to } \\
\text { neutral }\end{array}$ & Scarce \\
\hline 7. Lecturer receives $€ 100$ as a reward. & Neutral to great & Neutral & Neutral \\
\hline 8. Lecturer receives a total expense payback. & Neutral to great & Neutral & Neutral \\
\hline $\begin{array}{l}\text { 9. Management communicates with lecturer about the preconditions } \\
\text { and the amount of the reward. }\end{array}$ & Great & Reasonable & Substantially \\
\hline 10. Lecturer receives a coupon of $€ 75$ as reward. & Neutral to great & $\begin{array}{l}\text { Unreasonable to } \\
\text { neutral }\end{array}$ & Scarce \\
\hline
\end{tabular}

On the basis of the underlying results, reliable statements can be made as to whether lecturers at universities of applied sciences believe the deployment of differentiated rewards to be justified in a process of lecturer professionalisation.

The most important outcome of this study is that lecturers at universities of applied sciences believe it justified that differentiated rewards are deployed in order to have them develop and/or display more professionalism. It was also found that, under specific conditions, it encouraged these lecturers to show more willingness to further professionalise or display more professionalism.

The study made a good start in clarifying that lecturers at universities of applied sciences believe it justified that forms of reward differentiations are deployed to stimulate lecturer professionalisation. We now recommend a large-scale follow-up study, so that more data can be collated and the composition of the group of participants will be more heterogeneous. This would also contribute to the generalizability of the research findings.

This was the very first study into whether lecturers at universities of applied sciences believe it fair that differentiated rewards are deployed (in order for them to develop and/or display more professionalism) and to what extent, and under which conditions, these stimulate their willingness to do so. A reference framework is virtually non-existent. The research findings confirm that lecturers at universities of applied sciences appreciate financial stimuli, but that elements such as consultation, respect, coordination, and communication are appreciated even more. This is a good argument for a critical review of the existing HRM policy and an appeal to HRM to design new systematics that has a far more stimulating effect on personal and professional growth in subject-specific knowledge, practical experience, lecture skills, and performing in a team.

Hess Rice [9] stated that financial gain was a powerful, appealing, and initial stimulus in a process of professionalisation and that this stimulus should be used as a booster within a professionalisation process.

This study showed that lecturers at universities of applied sciences believed it justified that differentiated rewards were deployed in order to have them develop and display more professionalism. It was also found that under specific conditions they encouraged these lecturers to show more willingness to further professionalise or display more professionalism. Nevertheless, additional research is desirable. The private sector has been using financial stimuli to enhance professionalisation for quite some time now. Which of their insights and assumptions might be successfully adopted by a university of applied sciences? 


\section{Biographical Notes}

Jol Stoffers is professor of Employability (lector) at Zuyd University of Applied Sciences (Faculty of Management \& Law) in the Netherlands. He leads the Research Centre of Employability, and his research focuses on Employability (HRM), Leadership and Innovative Work Behaviour. Next to that he is academic program manager of the master of Personal Leadership in Innovation and Change.

Jol Stoffers holds a PhD in Management Science from the Radboud University (Institute for Management Research), and an executive MBA (Master of Business Administration) of Maastricht University. More than fifteen years he worked as a manager and senior HRM consultant in the insurance and recruiting industry.

Erik Canisius is senior lecturer at Zuyd University of Applied Science (Faculty of Management \& Law) and researcher at the Research Centre of Employability in the Netherlands. He holds a Master of Science degree in Strategic Human Resource Management from the Open University in the Netherlands. For ten years he worked as an HRM manager in different businesses in several economic sectors, and more than five years he worked as a policy advisor "labour market" at the provincial government.

\section{References}

[1] Veen van, K., Zwart, R., Meirink, J. and Verloop, N. (2010) Professionele ontwikkeling van leraren. Iclon/Expertisecentrum Leren van Docenten, Leiden.

[2] Sociaal Economische Raad (2011) Strategische agenda voor hoger onderwijs, onderzoek en wetenschap. SER, Den Haag.

[3] Onderwijsraad (2011) Ruim baan voor stapsgewijze verbetering. Onderwijsraad, Den Haag.

[4] Diepstraten, I., Wassink, H., Stijnen, S., Martens, R. and Claessen, J. (2010) Professionalisering van leraren op de werkplek. Jaarboek Ruud de Moor Centrum. Open Universiteit Nederland, Heerlen.

[5] Martens, R.L. (2010) Zin in onderzoek: Docentprofessionalisering. Open Universiteit Nederland, Heerlen.

[6] Latham, G.P. and Pinder, C.C. (2005) Work Motivation Theory and Research at the Dawn of the Twenty-First Century. Annual Review of Psychology, 56, 485-516. http://dx.doi.org/10.1146/annurev.psych.55.090902.142105

[7] Watt, H.M.G. and Richardson, P.W. (2008) Motivations, Perceptions, and Aspirations Concerning Reaching as a Career for Different Types of Beginning Lecturers. Learning and Instruction, 18, 408-428. http://dx.doi.org/10.1016/j.learninstruc.2008.06.002

[8] Hildebrandt, S.A. and Eom, M. (2011) Teacher Professionalization: Motivational Factors and the Influence of Age. Teaching and Teaching Education, 27, 416-423. http://dx.doi.org/10.1016/j.tate.2010.09.011

[9] Hess Rice, E. (2002) The Collaboration Process in Professional Development Schools: Results from a Meta-Ethnography: 1990-1998. Journal of Teacher Education, 53, 55-67. http://dx.doi.org/10.1177/0022487102053001006

[10] Clugston, M., Howell, J.P. and Dorman, P.W. (2000) Dispositional Influences on Pay Preferences. Journal of Business and Psychology, 15, 311-320. http://dx.doi.org/10.1023/A:1007824118977

[11] Ballou, D. and Podgursky, M. (1993) Teachers' Attitudes toward Merit Pay: Examining Conventional Wisdom. Industrial and Labor Relations Review, 47, 50-61. http://dx.doi.org/10.2307/2524231

[12] Chamberlin, R., Wragg, T., Haynes, G. and Wragg, C. (2002) Performance-Related Pay and the Teaching Profession: A Review of the Literature. Research Papers in Education, 17, 31-49. http://dx.doi.org/10.1080/02671520110102534

[13] Solmon, L.C. and Podgursky, M. (2000) The Pros and Cons of Performance-Based Compensation. Milken Family Foundation, Santa Monica.

[14] Hay Management Consultants (2000) Beloningsdifferentiatie bij de provincies. http://shared.caop.nl/downloads/arbeidsvoorwaarden/provincies/Beloningsbeleid_bijlage1.pdf

[15] Mulders, R. (2005) Zes redenen waarom prestatiebeloning niet werkt. Management Team, 27, 30-36.

[16] van der Heijden, B.I.J.M. (2003) Organisational Influences upon the Development of Occupational Expertise throughout the Career. International Journal of Training and Development, 7, 142-165. http://dx.doi.org/10.1111/1468-2419.00178

[17] Ambrose, M.L. (2002) Contemporary Justice Research: A New Look at Familiar Questions. Organizational Behavior and Human Decision Processes, 89, 803-812. http://dx.doi.org/10.1016/S0749-5978(02)00030-4

[18] Saunders, M., Lewis, P. and Thornhill, A. (2012) Research Methods for Business Students. Pearson Education Ltd., Harlow.

[19] Rossi, P.H. and Nock, S.L. (1982) Measuring Social Judgments: The Factorial Survey Approach. Sage Publications, London. 
[20] Ganong, L.H. and Coleman, M. (2006) Multiple Segment Factorial Incentives and Student Outcomes. The Journal of Human Resources, 37, 913-927.

[21] Ajzen, I. and Fishbein, M. (1977) Attitude-Behavior Relations: A Theoretical Analysis and Review of Empirical Research. Psychological Bulletin, 84, 888-918. http://dx.doi.org/10.1037/0033-2909.84.5.888 